\title{
VARIATION OF WOOD DENSITY AND FIBRE LENGTH IN SIX WILLOW CLONES (SALIX SPP.)
}

\author{
Silvia Monteoliva1, Gabriela Senisterra² \& Raúl Marlats ${ }^{2,3}$
}

\begin{abstract}
SUMMARY
The variability of wood basic density and fibre length was determined in six 13-year-old willow clones growing under two different site conditions in Argentina. Values of basic density and wood fibre length were obtained and variance analyses were performed considering site and clone as sources of variation. Components of genetic and phenotypic variations were determined to calculate heritability in the broad sense. Site influence was significant for basic density, which ranged from $0.364 \mathrm{~kg} / \mathrm{dm}^{3}$ and $0.455 \mathrm{~kg} / \mathrm{dm}^{3}$. Clones "americano" and hybrid cv "A 13-44" showed the highest density values in both sites. For fibre length, values of the continental site were significantly higher. For each clone, mean values vary between $837.1 \mu \mathrm{m}$ and $1142.1 \mu \mathrm{m}$. Heritability values show that the genetic control is stronger for density $\left(\mathrm{h}^{2}=0.65\right)$ than for fibre length $\left(\mathrm{h}^{2}=\right.$ 0.32 ). The clones "americano" and "13-44" stand out because of their high density and long fibres.
\end{abstract}

Key words: Salix spp., clones, site variation, heritability, wood density, fibre length, wood quality.

\section{INTRODUCTION}

Species of the genus Salix (willows) have among their advantages two remarkable characteristics that promote their cultivation. One of them is that they are adapted to thrive in flooding environments, and the other is their easy vegetative propagation. The region called "Delta del Paraná", Argentina is the largest area of the world with planted clones of the genus Salix. Wood produced from willow is an essential supply for the largest newsprint mill in the country.

The genetic programmes concerning willows investigate how to maintain their wide range of adaptability to different environmental conditions, while simultaneously improving wood quality, specifically wood density and fibre length.

Wood basic density is considered one of the most important features in genetic improvement programmes (Zobel \& Talbert 1988) and is one of the most often studied wood quality traits (Bonavia de Guth 1981; Carrizo et al. 1997; Downes et al. 1997;

1) Cátedra de Dendrología, Facultad de Ciencias Agrarias y Forestales, Universidad Nacional de La Plata, CC 31 (1900) La Plata, Argentina.

2) Cátedra de Silvicultura, Facultad de Ciencias Agrarias y Forestales, Universidad Nacional de La Plata, CC 31 (1900) La Plata, Argentina.

3) Comisión Investigaciones Científicas Provincia Buenos Aires. 
Peszlen 1998). It is a complex feature influenced by cell wall thickness, the proportion of the different kind of tissues, and the percentages of lignin, cellulose and extractives (Valente et al. 1992). Both wood density and fibre length determine whether the quality of raw material is suitable for a specific use in the paper industry. Fibre length also has impacts on paper characteristics, such as strength, optical properties and surface quality.

References on these two variables concerning their heritability in the genus Salix are scarce. However, data for the related genus Populus (both members of the family Salicaceae) are presented by Yanchuk et al. (1984) and Peszlen (1998). They calculated heritabilities for density and fibre length and established proportions of genetic control on both parameters.

Knowledge of the genetic and environmental variation present in forest stands allows the development of adequate strategies for the selection of superior genotypes. A higher variability also permits a higher gain obtained by selection.

Before expanding the cultivation area of willows it is necessary to assess if values of wood characteristics are maintained in new environments. It is known that site influences growth in height, diameter, and yield of plantations, but the impacts of site on wood quality has not been well studied.

For the most cultivated clones of Salix in Delta del Río Paraná, Argentina, partial estimations of density and fibre morphology have been performed (Bonavía de Guth 1980, 1981; Bonavía de Guth \& Piussan 1987). Only for Salix nigra several sites have been studied (Bonavía de Guth 1984).

The aim of the present work was to determine the variability of wood basic density and fibre length in six willow clones (Salix spp.), growing under two different site conditions.

\section{MATERIALS AND METHODS}

\section{Site characterisation}

Wood samples of willow clones were obtained from two sites:

Site 1) Continental: Estación Experimental Julio Hirschhorn, Facultad de Ciencias Agrarias y Forestales, Universidad Nacional de La Plata ( $34^{\circ} 55^{\prime} \mathrm{S} ; 57^{\circ} 57^{\prime} \mathrm{W}$; elevation $5 \mathrm{~m}$ asl), Los Hornos, Buenos Aires, Argentina. Soils are characteristic of the centre-east of the province, identified as argiudoll typical, fine, illitic, termic; normal relief. Climate: mean maximum temperature is $22.6^{\circ} \mathrm{C}$, mean minimum temperature $10.2^{\circ} \mathrm{C}$, absolute maximum temperature $42.7^{\circ} \mathrm{C}$ (December) and absolute minimum temperature $-5.7^{\circ} \mathrm{C}$ (June). Annual precipitation value is $1100 \mathrm{~mm}$, with an isohydric regime.

Site 2) Delta Medio del Río Paraná: Establecimiento Las Animas, Villa Paranacito, Entre Ríos, Argentina $\left(33^{\circ} 45^{\prime}\right.$ and $\left.33^{\circ} 26^{\prime} \mathrm{S} ; 59^{\circ} 01^{\prime} \mathrm{W}\right)$. Hydracuent systematised soils of the south of the province of Entre Ríos, with flood control dams. Floods are recurrent events causing long periods of inundation. Climate: mean maximum tem-perature is $24.5^{\circ} \mathrm{C}$, mean minimum temperature $9.2^{\circ} \mathrm{C}$, absolute maximum temperature $40^{\circ} \mathrm{C}$ (December), and absolute minimum temperature $-5^{\circ} \mathrm{C}$ (June). The value of mean precipitation is $978 \mathrm{~mm}$, with an isohydric regime. 
Samples were extracted from six 13-year-old clones, planted at a density of 1111 plants / hectare (spacing: $3 \times 3 \mathrm{~m}$ ).

\section{Parental characterisation of evaluated clones (Table 1)}

Table 1. Studied clones, parental origins and provenances.

\begin{tabular}{lll}
\hline Clones & Parental origin & Provenance \\
\hline "americano" & Salix babylonica var. sacramenta & Russia \\
Hybrid cv "A 131-25" & Salix babylonica $\times$ Salix alba & INTA Castelar, Argentina \\
Hybrid cv "A 131-27" & Salix babylonica $\times$ Salix alba & INTA Castelar, Argentina \\
Hybrid cv “A 13-44" & Salix matsudana $\times$ Salix alba & INTA Castelar, Argentina \\
Hybrid cv "NZ 26992" & Salix matsudana $\times$ Salix alba & New Zealand \\
Hybrid cv "A 250-33" & Salix babylonica $\times$ Salix alba & INTA Castelar, Argentina \\
\hline
\end{tabular}

\section{Determination of wood basic density $\left(\mathrm{kg} / \mathrm{dm}^{3}\right)$ and fibre length $(\mu \mathrm{m})$}

Five trees per clone and site, with undamaged wood, were selected. Border trees were avoided. Two samples/tree at breast height $(1.30 \mathrm{~m})$ were extracted. One was used to determine density and the other one to carry out fibre length measurements.

Basic density was determined after TAPPI standard $N^{\circ}$ 258-om-94 (Technical Association of the Pulp and Paper Industry), calculating the ratio between dry weight of the sample and saturated volume in complete discs, after removal of their bark.

For fibre length characterisation, samples located on the northern radius corresponding to three radial positions (inner, intermediate and outer) were obtained. Prior to measurement, material was dissociated using Franklin's maceration technique (1938), and then 30 fibres per position were measured using an Olympus microscope with image analyser.

Table 2. Expected mean squares.

\begin{tabular}{lll}
\hline Source of variation & Degrees of freedom & Expected mean squares \\
\hline Clones & $\mathrm{c}-1$ & $\sigma^{2}+\mathrm{t} \sigma_{\mathrm{cs}}^{2}+\mathrm{st} \sum_{\mathrm{i}}^{\mathrm{c}} \mathrm{C}_{\mathrm{i}}^{2}$ \\
Sites & $\mathrm{s}-1$ & $\sigma^{2}+\mathrm{cto}_{\mathrm{s}}^{2}$ \\
Clone $\times$ site & $(\mathrm{c}-1)(\mathrm{s}-1)$ & $\sigma^{2}+\mathrm{t \sigma}_{\mathrm{cs}}^{2}$ \\
Error & $\mathrm{cs}(\mathrm{t}-1)$ & $\sigma^{2}$ \\
\hline
\end{tabular}

$\mathrm{c}=$ number of clones; $\mathrm{s}=$ number of sites $; \mathrm{t}=$ numbers of ramets per clone per site $; \sigma^{2}{ }_{\mathrm{c}}=$ variance due to difference between clones; $\sigma^{2}{ }_{\mathrm{s}}=$ variance due to difference between sites; $\sigma^{2}{ }_{\mathrm{cs}}=$ variance due to the interaction of clones and sites; $\sigma^{2}=$ variance of error. 


\section{Statistical analysis}

Variance analysis was carried out with site and clone as sources of variation (Table 2). When significant differences were detected, Tukey's test of comparison of mean values was applied.

After the analysis of variance of the data, components of phenotypic and genetic variance were determined in order to calculate the heritability in the broad sense for both sites using the following expression:

$$
\mathrm{h}_{2}=\frac{\mathrm{Vg}}{\mathrm{Vp}}=\frac{\mathrm{Vg}}{\mathrm{Vg}+\mathrm{Vga}+\mathrm{Ve}}
$$

where:

$\mathrm{h}_{2}=$ heritability in the broad sense

$\mathrm{Vg}=$ genetic variance

$\mathrm{Vp}=$ phenotypic variance

$\mathrm{Vga}=$ variance of the interaction of genotypes with the environments

$\mathrm{Ve}=$ variance of error

The following model was employed (genotypes were considered as fixed effects and sites as randomised effects):

$$
\begin{aligned}
& Y_{i j k}=\mu+C_{i}+S_{j}+C S_{i j}+e_{i j k} \\
& Y_{i j k}=\text { phenotypic value } \\
& \mu=\text { general mean value } \\
& C_{i}=\text { effect of clone } \\
& S_{j}=\text { effect of site } \\
& C S_{i j}=\text { effect of the interaction of clone and site } \\
& e_{i j k}=\text { experimental error associated to the } k^{\text {th }} \text { tree of clone } i \text { in the site } j
\end{aligned}
$$

\section{RESULTS AND DISCUSSION}

\section{Basic density and fibre length}

Tables 3 and 4 present results of the analysis of variance for individual tree data. Significant differences were found between clones and sites. Interactions between sources of variation were not significant. Bonavía de Guth (1984) determined significant differences in average density in different sites for Salix nigra. In contrast, Peszlen (1998) did not detect differences for density in three clones of the genus Populus planted in two sites in Hungary.

Table 5 indicates that clones 26992, 131-25, 131-27 and 250-33 belong to a subgroup of lower density without significant differences among them. Clones 13-44 and "americano" correspond to the higher density range in both sites.

Basic density values between $0.364 \mathrm{~kg} / \mathrm{dm}^{3}$ and $0.455 \mathrm{~kg} / \mathrm{dm}^{3}$ were found in this study. The range of variation between clones agrees with that observed in previous studies carried out in the country (Bonavía de Guth \& Ragonese 1980; Bonavía de Guth1982; Piussan et al. 1990).

Mean fibre length values for each clone vary between $837 \mu \mathrm{m}$ and $1142 \mu \mathrm{m}$. For pulp and paper production, species with higher lengths are preferred since a better fibre 
Table 3. Analysis of variance for wood basic density in both sites.

\begin{tabular}{lccc}
\hline Source of variation & Degrees of freedom & Mean squares & F \\
\hline Clones & 5 & 0.00784 & $28.43^{* *}$ \\
Site & 1 & 0.00592 & $13.66^{* *}$ \\
Clone $\times$ site & 5 & 0.00028 & $0.636 \mathrm{~ns}$ \\
Residual & 48 & 0.00043 & \\
\hline
\end{tabular}

Table 4. Analysis of variance for fibre length in both sites.

\begin{tabular}{lccc}
\hline Source of variation & Degrees of freedom & Mean squares & F \\
\hline Clones & 5 & 63991.5 & $4.82^{* *}$ \\
Site & 1 & 34336.6 & $4.13^{* *}$ \\
Clone $\times$ site & 5 & 13269.0 & $1.59 \mathrm{~ns}$ \\
Residual & 48 & 8314.48 & \\
\hline
\end{tabular}

Table 5. Clone $\times$ site comparison of wood basic densities and fibre length Tukey's test for $\alpha \pm 0.05$.

\begin{tabular}{ccccccc}
\hline \multicolumn{3}{c}{ Density $\left(\mathrm{kg} / \mathrm{dm}^{3}\right)$} & & \multicolumn{3}{c}{ Fibre length $(\mu \mathrm{m})$} \\
\cline { 1 - 2 } \cline { 5 - 6 } Clone & Los Homos & Las Animas & & Clone & Los Homos & Las Animas \\
\hline 26992 & $0.364 \mathrm{a}$ & $0.379 \mathrm{a}$ & & 26992 & $875 \mathrm{a}$ & $837 \mathrm{a}$ \\
$131-25$ & $0.371 \mathrm{ab}$ & $0.377 \mathrm{a}$ & & $13-44$ & $959 \mathrm{~b}$ & $881 \mathrm{~b}$ \\
$131-27$ & $0.375 \mathrm{ab}$ & $0.405 \mathrm{~b}$ & & $131-27$ & $988 \mathrm{c}$ & $888 \mathrm{~b}$ \\
$250-33$ & $0.384 \mathrm{ab}$ & $0.395 \mathrm{ab}$ & & $250-33$ & $1008 \mathrm{~cd}$ & $979 \mathrm{bc}$ \\
americano & $0.405 \mathrm{bc}$ & $0.437 \mathrm{c}$ & & $131-25$ & $1023 \mathrm{~d}$ & $909 \mathrm{~b}$ \\
$13-44$ & $0.431 \mathrm{c}$ & $0.455 \mathrm{c}$ & americano & $1056 \mathrm{e}$ & $1142 \mathrm{~d}$ \\
\hline
\end{tabular}

Same letter group treatments without significant differences.

net is achieved, resulting in a higher resistance of the paper. This is the reason why clones with fibres longer than one millimetre like "americano", 131-25 and 250-33 are preferred. It is interesting that "americano" is the only clone that overcomes the millimetre limit at both sites in agreement with values reported by Bonavía de Guth and Ragonese (1981), Bonavía de Guth (1987), García Volonté (1989), and Monteoliva et al. (2002).

The site of plantation influenced all the clones. Values were significantly higher in the continental site (Los Hornos), except for clone "americano" that showed a lower length in that site. However, it maintained its superiority in respect the other tested clones. 


\section{Heritability of the studied features}

Heritability in the broad sense is defined as the ratio of total genetic variance to phenotypic variance. The most important function of this parameter is its predictive role. Since this study considers six clones only, the results should be interpreted with caution due to the small sample size.

An estimate of $h^{2}=0.65$ was obtained for wood basic density and 0.32 for fibre length. In other studies, Peszlen (1998) found a heritability of 0.51 for basic density in three Populus clones planted in Hungary. Yanchuk et al. (1984) determined heritabilities of 0.35 for density and 0.43 for fibre length in populations of Populus tremuloides. They emphasised that both these traits were under a moderate genetic control.

In view of the multipurpose role of Salix species, the possibilities of increasing the cultivation area to provide raw material for the paper industry requires a deeper knowledge of their genetics.

\section{REFERENCES}

Bonavía de Guth, E. 1981. Características del leño de varias especies e híbridos de Salix, en apoyo a la obtención de buenos clones papeleros. $17^{\circ}$ Congreso de ATIPCA, Tomo 1: F25-F32.

Bonavía de Guth, E. 1982. Evaluación de varios híbridos obtenidos por cruzamiento de Salix alba por Salix matsudana. $18^{\circ}$ Congreso de ATIPCA. Trabajos Técnicos, Tomo 2: 20-30.

Bonavía de Guth, E. 1984. Salix nigra: características del leño según zona de implantación en el Delta del Paraná. $20^{\circ}$ Congreso de ATIPCA.Trabajos Técnicos: 71-86.

Bonavía de Guth, E. \& C. M. Piussan. 1987. Variación de las características del leño del individuo en Salix nigra cultivado en el Delta del Paraná. CIEF. Simposio sobre silvicultura y mejoramiento genético de especies forestales. Tomo IV: 219-235.

Bonavía de Guth, E. \& A. Ragonese. 1980. Evaluación de las características del leño en relación a la calidad del papel de algunos híbridos de sauces obtenidos en Castelar (INTA). IDIA no 393-394: $25-30$.

Carrizo, G.L., A. B. Guarnaschelli \& S.F. de Delfino. 1997. Asociación entre madera juvenil y adulta en Populus deltoides subesp. angulata. II Congreso Forestal Argentino y Latinoamericano, "Forestar y crecer": 6 pp.

Downes, G. M., I. L. Hudson, C. A. Raymond, A. J. Dean, A. J Michell, L. R. Schimleck, R. Evans \& A. Muneri. 1997. Sampling Eucalypts for wood and fibre properties. CSIRO Publishing, Australia.

Franklin, G.L. 1938. The preparation of woody tissues for microscopic examination. For. Prod Res. Lab. 40.

García Volonté, R. \& E. A. Suárez. 1989. Características de algunos sauces para la producción de papel para diarios. Primeras Jornadas sobre silvicultura y mejoramiento genético del género Salix. CIEF. Actas: $139-144$.

Monteoliva, S., G. Senisterra, J. L. Marquina, R. M. Marlats \& G. R. Ciocchini. 2002. Clones de sauce, longitud de fibras en su madera. Rev. FCA UNCuyo, Tomo XXXIV, No 2: 49-56.

Peszlen, I. 1998. Variation in specific gravity and mechanical properties of poplar clones. Drevársky Výskum 43 (2): 1-17.

Piussan, M., R. Repetti \& E. A. Fontana. 1990. Estudio comparativo de las propiedades papeleras del Salix nigra No 4, del híbrido A-131/27 y del sauce americano. $26^{\circ}$ Congreso de ATIPCA. Trabajos Técnicos: 485-504.

Valente, C. A., A. Mendes de Sousa, F.P. Furtado \& A.P. de Carvalho. 1992. Improvement program for Eucalyptus globulus at PORTUCEL: Technological component. Appita 45: 403-407.

Yanchuk, A.D., B.P. Dancik \& M.M. Micko. 1984. Variation and heritability of wood density and fibre length of trembling aspen in Alberta, Canadá. Silvae Genetica 33: 11-16.

Zobel, B. \& J. Talbert. 1988. Técnicas de mejoramiento genético de árboles forestales. Editorial Limusa. 